\title{
PELATIHAN RETORIKA DAN MENULIS TEKS CERAMAH KELAS XI SMK NUSANTARA O2 KESEHATAN (KORELASI MENULIS TEKS CERAMAH DAN PRAKTIK RETORIKA)
}

\author{
Dwi Septiani' ${ }^{1}$, Rerin Maulinda ${ }^{2)}$, Desi Karolina Saragih ${ }^{3)}$, Aryani ${ }^{4)}$ \\ Universitas Pamulang \\ Email: dosen01401@unpam.ac.id ${ }^{1)}$, dosen00445@unpam.ac.id ${ }^{2)}$, dosen01414@unpam.ac.id ${ }^{3)}$, \\ dosen01161@unpam.ac.id ${ }^{4)}$
}

\begin{abstract}
Writing skills are an important aspect of academic performance as well as performance related to active skills that must be mastered, including in class XI SMK students. However, there are still many students who are not good at it, including writing lecture texts. Apart from the lack of skill in writing lecture texts, advanced stages such as rhetoric practice (lectures) are still low. Thus, this study focuses on examining the correlation between lecture text writing skills and achievement in rhetorical practice (lecture). The method used in this research is descriptive quantitative method with 50 participants of class XI SMK 02 Nusantara Kesehatan who have previously participated in online Community Service (PKM) activities carried out by the Indonesian Literature Study Program at Pamulang University with the theme \&quot;Rhetorical Practical Online Training in Writing Skills. Text of the Class XI Student Lecture at SMK Nusantara 02 Kesehatan \&quot;which was held 7-1 September 2020 with Google Meet media. The result of this study is a very significant influence between the skill of writing lecture texts $(\mathrm{X})$ on the achievement of rhetoric practice $(\mathrm{Y})$, which is 0.926 . In addition, there is a contribution made by the skill of writing lecture texts $(\mathrm{X})$ to the achievement of rhetoric practice $(\mathrm{Y})$, which is $85.8 \%$.
\end{abstract}

Keywords: Lecture text, rhetoric practice, writing skills

\section{ANALISIS SITUASI}

Pendidikan adalah salat satu elemen terpenting dalam proses persaingan global, khususnya dalam era Revolusi Industi 4.0 ini. Revolusi Industi 4.0 membawa banyak perubahan, termasuk dalam sektor pendidikan. Pembelajaran harus mampu mengintergrasikan pemanfaatan teknologi informasi. Perubahan pendidikan konvensional dengan pertemuan tatap muka di kelas mulai berubah menjadi pertemuan virtual dalam pengajaran dan pembelajaran. Tahun 2000-an, beberapa perguruan tinggi di Indonesia identik dengan pemanfaataan teknologi informasi yang umumnya sudah terintegrasi dengan pembelajaran daring. Namun, saat ini, saat pandemi virus Covid-19 yang telah melumpuhkan hampir seluruh dunia, termasuk Indonesia, hampir semua level pendidikan, dari prasekolah sampai dengan SMA/MA/SMK juga harus mampu berpartisipasi dalam pemanfaatan teknologi informasi dalam pembelajaran jarak jauh (PJJ/ daring/ online).

Faktanya, fenomena ini membawa tantangan tersendiri untuk lembaga dan para pengajar dalam menyelanggarakan proses pembelajaran yang efektif dan invotaif serta mengintegrasikan teknologi di dalamnya. Salah satu pembalajaran yang bersiap untuk menghadapi situasi ini adalah pembelajaran bahasa, tepatnya Bahasa Indonesia di level SMK. Pengajar tidak hanya menyampaikan materi bahasa secara virtual, tetapi pengajar juga dapat melakukan penilaian atau evaluasi atas tugas yang dikerjakan peserta didik dengan dengan memanfaatkan produk teknologi berbasis internet.

Salah satu materi dalam mata pelajaran Bahasa Indonesia di kelas XI SMK adalah materi menulis teks ceramah dan praktik ceramah. Namun, berdasarkan observasi saat pembelajaran tatap muka, sebagian besar 
siswa masih kurang baik dalam menulis teks ceramah dan masih kurang percaya diri dalam melakukan praktik retorika (ceramah) di depan kelas. Diharapkan dengan adanya integrasi teknologi informasi yang dimiliki para siswa agar mampu meminimalisasi berbagai kendala dalam pembelajaran bahasa, khususnya dalam kedua materi tersebut.

Dalam pembelajaran bahasa Indonesia di SMK Nusantara 02 Kesehatan, kedua materi tersebut sudah diintegrasikan dengan pemanfaatan teknologi, seperti penggunaan G-mail serta Google Meet dalam penyampaian materi ajar dari pengajar kepada siswa. Selain itu, kedua aplikasi tersebut dapat digunakan para siswa untuk mengirimkan teks ceramah yang dibuatnya dengan Gmail serta melakukan praktik ceramah (retorika) secara langsung dengan Google Meet. Kerja sama antara para pengajar dan para siswa harus terjalin dengan harmonis agar pembelajaran vritual ini tetap berjalan sesuai rencana.

Berdasarkan hal di atas, Tim Dosen dan Mahasiswa dari Program Studi Sastra Indonesia Universitas Pamulang melakasanakan salah satu Tri Dharma Perguruan Tinggi, yakni menyelenggarakan Pengabdian Kepada Masyarakat (PKM) di SMK 02 Nusantara Kesehatan yang berjudul "Pelatihan Daring Praktik Retorika dalam Keterampilan Menulis Teks Ceramah Siswa Kelas XI di SMK Nusantara 02 Kesehatan". Kegiatan PKM ini dilaksanakan secara virtual atau daring (online) menggunakan media Google Meet pada 7-11 September 2020, pukul 13.00-15.00 WIB. Kegiatan ini disambut dengan sangat antusias oleh pihak sekolah dan para siswa (partisipan). Selama kegiatan PKM berlangsung, ada 4 guru pendamping dan sekitar 80 para siswa yang berpartisipasi pada kegiatam PKM virtual ini. Selain melaksanakan kegiatan PKM virtual, tim dosen juga melaksanakan penelitian tindakan kelas (PTK) dengan judul "Korelasi Kemampuan Menulis Teks Ceramah terhadap Praktik Retorika Berbasis Daring Siswa Kelas XI SMK Nusantara 02 Kesehatan”.

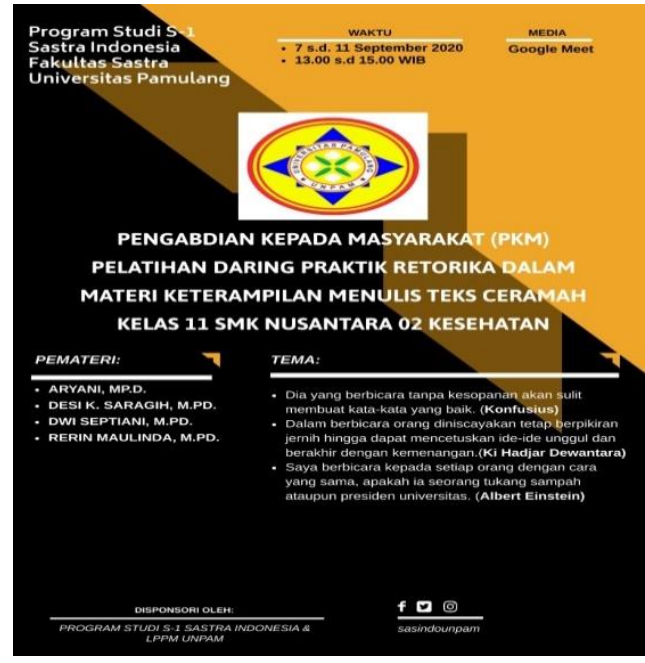

Gambar 1: Poster Kegiatan PKM Berbasis Daring di SMK Nusantara 02 Ciputat

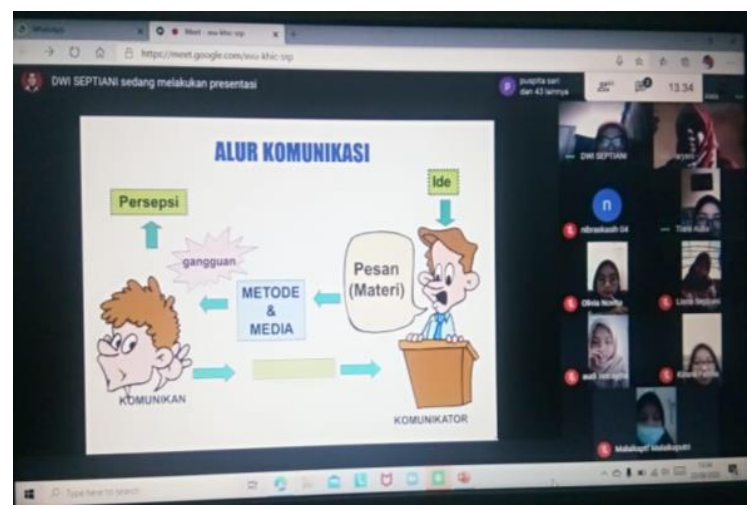

Gambar 2: Kegiatan PKM Berbasis Daring di SMK Nusantara 02 Ciputat

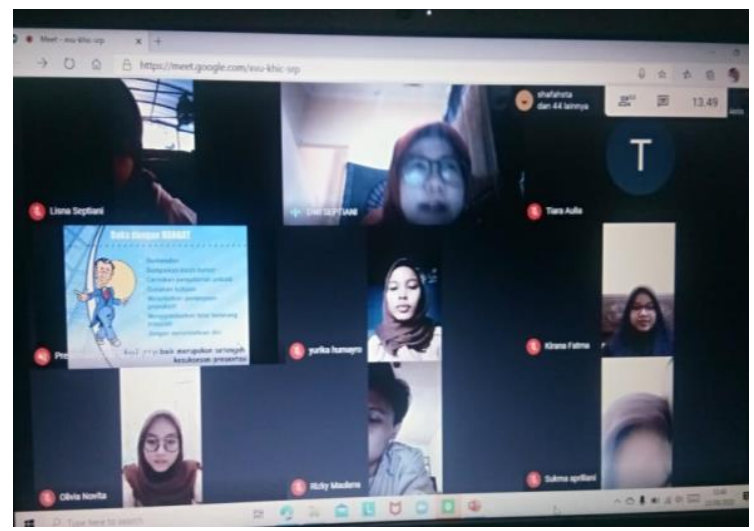

Gambar 3: Kegiatan PKM Berbasis Daring di SMK Nusantara 02 Ciputat

Dwi Septiani- Pelatihan Retorika Dan Menulis Teks Ceramah Kelas XI SMK N Nusantara 02 Kesehatan (Korelasi Menulis Teks Ceramah Dan Praktik Retorika) 
Dalam mengembangkan keterampilan menulis, berdasarkan wawancara peneliti dengan guru Mata Pelajaran Bahasa Indonesia, ternyata ada banyak kendala yang menghampiri, termasuk bagi siswa. Beberapa faktor mendasari perkembangan kontrol kognitif dalam penguasaan keterampilan menulis. Ini termasuk (1) pematangan memori kerja sepanjang masa remaja (Sowell, Thompson, Holmes, Jernigan, \& Toga, 1999), (2) strategi pembelajaran untuk prewriting, drafting, dan revisi yang mengatur tuntutan komposisi (Fayol, 1999), dan (3) pengambilan cepat pengetahuan spesifik domain dari memori jangka panjang bila diperlukan selama komposisi, sehingga menghindari kebutuhan penyimpanan sementara dalam memori kerja jangka pendek (McCutchen, 2000). Transformasi pengetahuan seperti itu membutuhkan representasi bersamaan dalam kerja memori ide-ide penulis dan makna teks (Traxler \& Gernsbacher, 1992). Ini juga membutuhkan koordinasi interaksi yang kompleks antara perencanaan, pembuatan, dan peninjauan.

Penguasaan keterampilan menulis di sekolah menengah harus sudah mampu menulis dengan ejaan yang benar, tanda baca, tata bahasa, diksi, pernyataan tesis, kalimat topik dan tautan kohesif dalam suatu paragraf, dan organisasi teks secara tepat. Salah satu penulisan teks yang harus dikuasai oleh para siswa kelas XI adalah teks ceramah. Penyusunan teks ceramah yang baik penting sekali dalam praktik ceramah. Teks ceramah yang baik dapat menjadi salah satu dasar kesuksesan dalam praktik ceramah. Jadi, sebelum melakukan praktik ceramah, siswa harus membuat teks ceramah dengan struktur dan aspek bahasa yang tepat.

Teks ceramah adalah proses memverbalkan gagasan atau ide kepada khalayak ramai tentang menginformasikan suatu hal, pengetahuan dan sebagainya yang terdiri atas tiga bagian, yaitu pembukaan, isi, dan penutup. Menurut Sari, dkk. (2019), dalam menulis teks ceramah ada yang harus diperhatikan, yakn pemilihan gagasan dan penggunaan bahasa. Ceramah yang baik harus memiliki maksud dengan jelas dan setiap bagian dalam kerangka ceramah hanya memiliki satu gagasan serta bagian-bagian dalam kerangka ceramah harus tersusun secara logis. Ceramah umumnya mempunyai empat ciri, yakni keterampilan berbahasa satu arah, dilakukan dalam keperluan belajar mengajar klasikal, pembicara berdiri di depan orang banyak untuk menyampaikan materi, sementara pendengar hanya menyimak, dan kegiatan pasif reseptif. Tujuan utama seseorang berceramah adalah menginformasikan, menghibur, membujuk, merayu dan mempengaruhi. Dengan demikian, tujuan umum ceramah digolongkan ke dalam beberapa jenis, yakni ceramah informatif, ceramah argumentatif, ceramah instruktif, ceramah persuasif, dan ceramah rekreatif.

Praktik ceramah adalah bagian dari ilmu retorika. Retorika adalah sebuah teknik persuasi verbal untuk memengaruhi degan cara emosional atau memaparkan argumen. Keterampilan berbicara yang baik pasti membutuhkan pengetahuan dan latihan. Ilmu retorika adalah "ilmu berbicara" yang harus dikuasai setiap insan. Retorika (rhetoric, rhetorica) adalah seni berbicara tentang bagaimana bertutur secara efektif. Retorika juga termasuk dalam bidang public speaking. Dengan demikian penjelasan tersebut memberikan pemahaman tentang keterampilan berbicara di depan umum, misalnya retorika atau ceramah. Berdasarkan penjelasan di atas, penelitian ini akan menganalisis adanya korelasi keterampilan menulis teks ceramah terhadap praktik retorika siswa kelas XI di SMK Nusantara 02 Kesehatan.

\section{METODE PELAKSANAAN}

Metode penelitian yang digunakan dalam penelitian ini adalah metode kuantitatif deskriptif. Menurut Bungin (2005), analisis kuantitatif deskriptif digunakan untuk menjelaskan, menjelaskan, atau meringkas berbagai kondisi, situasi, fenomena, atau 
variabel analisis yang bervariasi sesuai dengan peristiwa yang mungkin difoto, diwawancarai, diamati, dan yang mungkin diekspresikan melalui materi dokumenter. Bahan penelitian yang digunakan adalah hasil belajar siswa (nilai) dari guru mata pelajaran Bahasa Indonesia pada dua materi, yakni keterampilan menulis teks ceramah dan praktik retorika (ceramah). Analisis yang digunakan adalah analisis korelasional, yakni suatu studi yang melibatkan tindakan pengumpulan data, untuk melihat ada tidaknya hubungan dan juga tingkat hubungan antara 2 variabel atau lebih (Sukardi, 2003).

Variabel yang digunakan dalam penelitian ini ada dua varabel yang berasal dari daftar nilai guru Mata Pelajaran Bahasa Indonesia di SMK 02 Nusantara Kesehatan setelah para siswa kelas XI mengikuti serangkaian kegiatan "Pelatihan Daring Praktik Retorika dalam Keterampilan Menulis Teks Ceramah Siswa Kelas XI di SMK Nusantara 02 Kesehatan" secara virtual atau daring (online) dengan media Google Meet pada 7-11 September 2020. Data nilai siswa yang diambil adalah nilai keterampilan teks ceramah dan nilai praktik retorika (ceramah). Populasi target adalah siswa kelas XI SMK 02 Nusantara Kesehatan. Sampel sebanyak 50 siswa yang telah mengikuti kegiatan PKM. Adapun korelasi dua varibel dapat dilihat pada gambar di bawah ini.

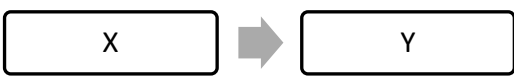

Gambar 4. Desain Penelitian

Keterangan:

$\mathrm{X}=$ Keterampilan Menulis Teks Ceramah $\mathrm{Y}=$ Praktik Retorika
Tabel 1. Data X dan Y

\begin{tabular}{|c|c|c|c|c|c|}
\hline No & $\mathbf{X}$ & $\mathbf{Y}$ & $\mathbf{N o}$ & $\mathbf{X}$ & $\mathbf{Y}$ \\
\hline $\mathbf{1}$ & 83 & 85 & $\mathbf{2 6}$ & 80 & 82 \\
\hline $\mathbf{2}$ & 76 & 78 & $\mathbf{2 7}$ & 76 & 78 \\
\hline $\mathbf{3}$ & 75 & 77 & $\mathbf{2 8}$ & 85 & 86 \\
\hline $\mathbf{4}$ & 77 & 78 & $\mathbf{2 9}$ & 76 & 78 \\
\hline $\mathbf{5}$ & 80 & 82 & $\mathbf{3 0}$ & 72 & 75 \\
\hline $\mathbf{6}$ & 78 & 78 & $\mathbf{3 1}$ & 75 & 78 \\
\hline $\mathbf{7}$ & 80 & 82 & $\mathbf{3 2}$ & 82 & 82 \\
\hline $\mathbf{8}$ & 78 & 82 & $\mathbf{3 3}$ & 74 & 80 \\
\hline $\mathbf{9}$ & 74 & 75 & $\mathbf{3 4}$ & 74 & 76 \\
\hline $\mathbf{1 0}$ & 84 & 85 & $\mathbf{3 5}$ & 80 & 82 \\
\hline $\mathbf{1 1}$ & 80 & 82 & $\mathbf{3 6}$ & 73 & 75 \\
\hline $\mathbf{1 2}$ & 82 & 84 & $\mathbf{3 7}$ & 86 & 85 \\
\hline $\mathbf{1 3}$ & 82 & 82 & $\mathbf{3 8}$ & 78 & 78 \\
\hline $\mathbf{1 4}$ & 78 & 80 & $\mathbf{3 9}$ & 80 & 82 \\
\hline $\mathbf{1 5}$ & 77 & 78 & $\mathbf{4 0}$ & 74 & 75 \\
\hline $\mathbf{1 6}$ & 80 & 84 & $\mathbf{4 1}$ & 80 & 82 \\
\hline $\mathbf{1 7}$ & 77 & 78 & $\mathbf{4 2}$ & 82 & 85 \\
\hline $\mathbf{1 8}$ & 82 & 84 & $\mathbf{4 3}$ & 78 & 80 \\
\hline $\mathbf{1 9}$ & 78 & 82 & $\mathbf{4 4}$ & 86 & 85 \\
\hline $\mathbf{2 0}$ & 75 & 78 & $\mathbf{4 5}$ & 78 & 80 \\
\hline $\mathbf{2 1}$ & 75 & 80 & $\mathbf{4 6}$ & 80 & 82 \\
\hline $\mathbf{2 2}$ & 72 & 75 & $\mathbf{4 7}$ & 76 & 78 \\
\hline $\mathbf{2 3}$ & 82 & 85 & $\mathbf{4 8}$ & 78 & 80 \\
\hline $\mathbf{2 4}$ & 75 & 78 & $\mathbf{4 9}$ & 78 & 80 \\
\hline $\mathbf{2 5}$ & 80 & 82 & $\mathbf{5 0}$ & 75 & 76 \\
\hline & & & & & \\
\hline
\end{tabular}

\section{HASIL DAN PEMBAHASAN}

Nilai keterampilan menulis teks ceramah dari beberapa partisipan terdapat rata-rata $($ mean $)=78,32$, median $=78$, modus (mode) $=80$, dengan standar deviasi sejumlah $=3,508$, nilai minimum $=72$, nilai maksimum $=86$, dan range skor $=14$. deskripisi tersebut, dapat diperoleh antara nilai rata-rata median hampir sama, yakni 78,32dan 78,00. Berdasarkan hal tersebut, data nilai menulis teks ceramah dalam penelitian.

cukup representatif. Dengan demikian, nilai menulis teks ceramah lebih tinggi jika dibandingkan median menunjukkan bahwa lebih banyak siswa yang memiliki keterampilan menulis teks ceramah lebih tinggi jika dibandingkan yang memiliki keterampilan menulis teks ceramah yang 
rendah. Para statistik modus dan mayoritas nilai menulis teks ceramah sebanyak 80 . Jumlah simpangan baku adalah 3,508 menunjukkan perbedaan keterampilan menulis teks ceramah responden tergolong tinggi. Dengan memperoleh bahwa nilai keterampilan menulis teks ceramah dari responden tergolong paling beragam di bawah rata-rata variabel jumlah praktik retorika, yaitu 3,182. Untuk lebih jelasnya, data dilihat dari tabel 2 di bawah ini.

Berdasarkan hasil pengolahan data, dioperoleh gambaran statistik deskriptif seperti pada tabel berikut.

Tabel 2. Analisis Deskriptif Statistics

\begin{tabular}{|c|c|c|c|}
\hline & $\begin{array}{c}\text { MENULIS } \\
\text { TEKS } \\
\text { CERAMAH } \\
\end{array}$ & $\begin{array}{r}\text { PRAKTIK } \\
\text { RETORIKA }\end{array}$ \\
\hline \multirow[t]{2}{*}{$\mathrm{N}$} & Valid & 50 & 50 \\
\hline & Missing & 0 & 0 \\
\hline \multicolumn{2}{|c|}{ Mean } & 78.32 & 80.28 \\
\hline \multicolumn{2}{|c|}{ Std. Error of Mean } & .496 & 450 \\
\hline \multicolumn{2}{|c|}{ Median } & 78.00 & 80.00 \\
\hline \multicolumn{2}{|c|}{ Mode } & 80 & 82 \\
\hline \multicolumn{2}{|c|}{ Std. Deviation } & 3.508 & 3.182 \\
\hline \multicolumn{2}{|c|}{ Variance } & 12.304 & 10.124 \\
\hline \multicolumn{2}{|c|}{ Skewness } & .286 & -.021 \\
\hline \multicolumn{2}{|c|}{$\begin{array}{l}\text { Std. Error of } \\
\text { Skewness }\end{array}$} & .337 & 337 \\
\hline \multicolumn{2}{|c|}{ Kurtosis } & -.467 & -1.002 \\
\hline \multicolumn{2}{|c|}{ Std. Error of Kurtosis } & .662 & .662 \\
\hline \multicolumn{2}{|c|}{ Range } & 14 & 11 \\
\hline \multicolumn{2}{|c|}{ Minimum } & 72 & 75 \\
\hline \multicolumn{2}{|c|}{ Maximum } & 86 & 86 \\
\hline \multicolumn{2}{|c|}{ Sum } & 3916 & 4014 \\
\hline
\end{tabular}

Skor praktik retorika (Y) yang didapat siswa dari para responden terdapat rata-rata $($ mean $)=80,28$, median 80, modus $($ mode $)=$ 82 , dalam standar deviasi sebesar $=3.182$, skor minimum $=75$, skor maksimum $=86$, serta range skor $=11$. Dari deskripisi tersebut, dapat dilihat bahwa antara nilai rata-rata dan median hampir sama, yakni 80,28 dan 80. Hal ini menunjukkan bahwa data skor praktik retorika (Y) pada penelitian ini cukup representatif. Selain itu, skor rata-rata (mean) praktik retorika (Y) lebih tinggi dibanding dengan median menunjukkan bahwa lebih banyak siswa yang memiliki praktik retorika (Y) lebih tinggi dibandingkan dengan yang memiliki praktik retorika $(\mathrm{Y})$ rendah. Menurut statistik modus, mayoritas skor praktik retorika (Y) adalah 82 . Skor simpangan baku 3,182 adalah menunjukkan perbedaan praktik retorika (Y) responden termasuk paling tinggi. Hal ini menunjukkan bahwa skor praktik retorika $(\mathrm{Y})$ dari responden termasuk beragam di atas variabel keterampilan menulis teks ceramah (X) 3.508.

Dengan pengujian standar analisis data yang didapat dalam penelitian tersebut adalah pengujian normalitas dan linieritas garis regresi dan variabel bebas, variabel terikat. $\mathrm{H}_{0}=$ sampel berdistribusi normal $\mathrm{H}_{1}=$ sampel tidak berdistribusi normal Dengan sistem pengujian:

Jika $\mathrm{a}_{\max }>\mathrm{D}_{\text {tabel }}: \mathrm{H}_{0}$ ditolak

Jika $\mathrm{a}_{\max }<\mathrm{D}$ tabel : $\mathrm{H}_{0}$ diterima

Kesimpualn dari data hasil uji normalitas dengan menggunakan program olah data SPSS versi 23.

Tabel 3. Uji Normalitas

One-Sample Kolmogorov-Smirnov Test

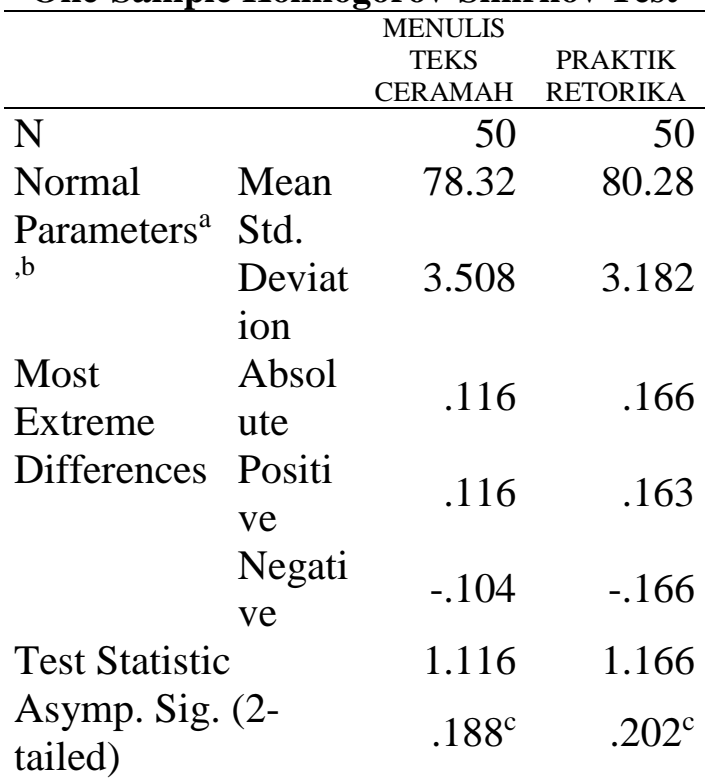
a. Test distribution is Normal.
b. Calculated from data.
c. Lilliefors Significance Correction.

Dari tabel uji normalitas di atas, pada kolom keterampilan menulis teks ceramah 
(X), terdapat nilai KolmogorovSmirnov= 1,116 dengan probabilitas 0,188 (Asymp. Sig. (2-tailed)). Persyaratan data berdistribusi normal jika probabilitas atau $\mathrm{p}>0,05$ pada uji normalitas Kolmogorov Smirnov. Jadi, karena nilai $\mathrm{p}=0,188$ atau $\mathrm{p}>0,05$ maka $\mathrm{H}_{0}$ diterima dan $\mathrm{H}_{1}$ ditolak. Artinya, data keterampilan menulis teks ceramah (X) berasal dari populasi yang berdistribusi normal.

Dalam kolom praktik retorika (Y), didapat nilai Kolmogorov-Smirnov $=1.166$ dan probabilitas 0,202 (Asymp. Sig. (2tailed)). Perlengkapan data berdistribusi normal yaitu probabilitas atau $\mathrm{p}>0,05$ pada uji normalitas . Jadi nilai $p=0,202$ atau $p>$ 0,05 maka $\mathrm{H}_{0}$ diterima dan $\mathrm{H}_{1}$ ditolak. kesimpulan, data praktik retorika (Y) berasal dari populasi yang berdistribusi normal. Dengan demikian, dapat dikatakan bahwa semua data dalam penelitian ini berasal dari populasi yang berdistribusi normal. Hal ini mengatakan salah satu prasyaratan uji $\mathrm{F}$ mengunakan penelitian ini cukup baik.

Langkah berikutnya adalah melakukan Uji Hipotesis. Uji hipotesis dapat dilihat dalam tabel di bawah ini.

Tabel 4 Model Summaryb

\begin{tabular}{lrrrr} 
Model & R & $\begin{array}{r}\text { R } \\
\text { Square }\end{array}$ & $\begin{array}{r}\text { Adjusted } \\
\text { R Square }\end{array}$ & $\begin{array}{r}\text { Std. Error of } \\
\text { the Estimate }\end{array}$ \\
\hline 1 & $.926^{\mathrm{a}}$ &, 858 &, 855 & 1,212
\end{tabular}

a. Predictors: (Constant), MENULIS TEKS CERAMAH

b. Dependent Variable: PRAKTIK RETORIKA

Dari tabel di atas, terlihat bahwa koefisien korelasi pengaruh variabel bebas keterampilan menulis teks ceramah (X) terhadap Prestasi praktik retorika (Y) adalah sebesar 0,926. Dalam jumlah perhitungan tersebut, diketahui bahwa koefisien korelasi tersebut valid pada keterampilan menulis teks ceramah $(\mathrm{X})$ terhadap Prestasi praktik retorika (Y). Koefisien determinasi yaitu angka pada kolom R squre pada kolom tersebut di atas dikalikan $100 \%$ yang menjelaskan besarnya kontribusi akan berpengaruh kepada variabel bebas $\mathrm{X}$ terhadap variabel terikat $\mathrm{Y}$. Berdasarkan hasil tersebut, dalam penelitian ini diperoleh koefisien determinasinya sebanyak $85,8 \%$ menunjukkan bahwa besarnya kontribusi keterampilan menulis teks ceramah $(\mathrm{X})$ dalam Prestasi praktik retorika (Y) didapat 85,8\%, sedangkan lebihnya $14,2 \%$ karena adanya pengaruh faktor lain.

Berdasarkan perhitungan atau analisis data di atas terlihat adanya pengaruh langsung yang signifikan antara keterampilan menulis teks ceramah $(\mathrm{X})$ terhadap Prestasi praktik retorika (Y) sebesar 0,926. Angka ini cukup tinggi karena dapat dimaknai sebagai hubungan yang sangat signifikan. Selain itu, ada kontribusi yang diberikan oleh keterampilan menulis teks ceramah (X) terhadap Prestasi praktik retorika (Y), yakni sebesar 85,8\%. Dengan demikian, 85,8\% keterampilan menulis teks ceramah (X) sangat berpengaruh terhadap prestasi siswa pada praktik retorika (Y), sedangkan sisanya 14,2\% mungkin dipengaruhi oleh faktor lain yang tidak dibahas dalam penelitian ini.

Keterampilan menulis teks ceramah (X) merupakan suatu keterampilan yang harus dimiliki para siswa. Dengan kata lain, para pengajar dapat memberikan materi yang kreatif dan infovatif tentang penyusunan teks ceramah yang baik. Penyusunan teks ceramah yang baik dapat memengaruhi kesuksesan dalam praktik retorika (ceramah). Hal ini didukung dengan penelitian yang telah dipaparkan di atas. Berdasarkan uraian di atas dan hasil penelitian, dapat disimpulkan bahwa seseorang yang memiliki keterampilan menulis teks ceramah yang tinggi akan menunjang keberhasilannya dalam keterampilan praktik retorika.

\section{KESIMPULAN}

Berdasarkan data yang diperoleh dan hasil analisis data serta pengujian hipotesis, dapat diambil simpulan bahwa kontribusi keterampilan menulis teks ceramah (X) termasuk dalam kategori kuat terhadap Prestasi praktik retorika (Y), yakni sebesar $85,8 \%$. Berdasarkan perhitungan dan pengolahan data diperoleh dengan nilai 
menulis teks ceramah siswa diperoleh dari responden terdapat nilai rata-rata $($ mean $)=$ 78.32 , median $=78.00$, modus $($ mode $)=80$, standar deviasi sebanyak $=3.508$, skor minimum $=72$, skor maksimum $=86$, serta range skor $=14$. Dengan demikian, dapat disimpulkan bahwa keterampilan menulis teks ceramah (X) siswa kelas XI SMK 02 Nusantara tergolong tinggi.

Skor praktik retorika (Y) siswa termasuk dalam kategori kuat, karena berdasarkan perhitungan dan pengolahan data yang dimiliki adalah rata-rata $($ mean $)=80.28$, median 80 , modus $($ mode $)=82$, standar deviasi sebesar $=3.182$, skor minimum $=75$, skor maksimum $=86$, serta range skor $=11$. Dari deskripisi tersebut, dapat dilihat bahwa antara nilai rata-rata dan median hampir sama, yakni 80.28 dan 80. Berdasarkan hasil tersebut, dapat disimpulkan bahwa praktik retorika (Y) siswa kelas XI SMK 02 Nusantara juga tergolong tinggi.

Oleh sebab itu, keterampilan menulis teks ceramah berperan sangat penting meningkatkan prestasi praktik retorika. Berdasarkan penjelasan hasil penelitian dalam analisis data dalam penelitian di atas, prestasi praktik retorika menjadi lebih baik dengan cara meningkatkan keterampilan menulis teks ceramah.

\section{DAFTAR PUSTAKA}

Bungin, Burhan. (2005). Metode Penelitian Kuantitatif. Jakarta: Prenadamedia.

Fitriana, Dewi Utami. (2016). Kunci Sukses Bicara Depan Publik. Yogyakarta: Pustaka Belajar.

Fayol, M. (1999) . From on-line Management Problems to Strategies in Written Composition, in $\mathrm{M}$. Torrance and G. Jeffery (Ed.), The Cognitive Demands of Writing. Amsterdam: Amsterdam University Press. 13-23.

McCutchen, D. (2000) . Knowledge, Processing, and Working Memory: Implications for a Theory of Writing.
Educational Psychologist, 35(1): 1323.

Sowell, E.R., P. M. Thompson, C. J. Holmes, T. L. Jernigan, dan A. W. Toga. (1999). In Vivo Evidence For PostAdolescent Brain Maturation In Frontal And Striatal Regions. Nature Neuroscience Volume 2, 859861(1999). DOI:10.1038/13154.

Sukardi. (2003). Metodologi Penelitian Pendidikan Kompetensi dan Prakteknya. Jakarta: Bumi Aksara.

Traxler, M. J., \& Gernsbacher, M. A. (1992). Improving written communication through minimal feedback. Language and Cognitive Processes, 7(1), 1-22. DOI:https://doi.org/10.1080/0169096 9208409378. 